\title{
Empathy-based marketing communication as a strategy to win the hearts of consumers during the Covid-19 pandemic
}

\author{
Sandika Hadit Prasetyo ${ }^{a, 1, *}$, Oktaviana Purnamasari ${ }^{\text {b,2 }}$ \\ ${ }^{a}$ Universitas Muhammadiyah Jakarta, Jl. K.H. Ahmad Dahlan, Cireundeu, Kec. Ciputat Tim., Kota Tangerang Selatan, Banten 15419 \\ ${ }^{1}$ sndkhadit@gmail.com*; \\ * corresponding author
}

\begin{abstract}
Article history

Received 09-11-2021

Revised 10-11-2021

Accepted 11-11-2021

Keywords

Pandemic

Marketing Communication

Empathy

The Covid-19 pandemic has affected many sectors including the economy. This situation forces companies to make significant changes in interacting with consumers through marketing communication activities. One of the marketing communication strategies used in pandemic situations is empathy-based marketing communication that promotes common interests and cares for others. This method aims to create a relationship, please help from all parties so that we can get through the difficult times of the pandemic together. Companies that have done this kind of thing include Burger King Indonesia, which carries out empathy-based marketing communications through the official Instagram account @ burgerking.id.This study aims to determine the response of the Burger King Indonesia target audience, both user and non-user, regarding their empathy-based marketing communication efforts. This research approach is qualitative with the interview method. The data collection technique was carried out by interviewing 8 BurgerKing target audiences consisting of 4 users and 4 non-users. The results of the study show that the Burger King target audience positively welcomes Burger King's efforts in empathy-based marketing communications. The majority of informants admitted that they were touched by the message conveyed by Burger King. Not only that, they also admitted that Burger King's image was getting better, furthermore there were sources who even had the desire to make purchases and spread the message on their social media.
\end{abstract}

This is an open access article under the CC-BY-SA license.

\section{Introduction}

At the end of 2019 a virus broke out in Wuhan, China. The virus called Covid-19 did not take long for Covid-19 to spread throughout the world until a pandemic phenomenon occurred. Of course (Sohrabi et al., 2020), the Covid-19 pandemic has made many changes around the world, from lock downs occurring in various countries, calls for wearing masks and maintaining distance are also being intensified in various parts of the world, it can even be said that due to the pandemic now the world is no longer the same (Lestari \& Sularso, 2020).

On March 11, 2020, the world health organization (WHO) announced that the spread of Covid19 was categorized as a pandemic. WHO says that determining the status of a pandemic is not something arbitrary because if it is misused it can cause chaos such as excessive fear to understanding that there is no hope ("WHO Coronavirus Disease (COVID-19) Dashboard," 2020).

The Covid-19 pandemic also affects not only the health sector but on all sectors, WHO said that all countries must strike a good balance between protecting health, minimizing economic and social disruption, and respecting human rights. The WHO mandate is public health. But we are working 
with many partners in all sectors to reduce the social and economic consequences of this pandemic. This is not just a public health crisis, it is a crisis that will touch every sector, so every sector and every individual must be involved in the struggle (Sohrabi et al., 2020).

Likewise what happened in Indonesia, the rapid spread of the corona virus has caused the government to issue several policies, one of which is large-scale social restrictions (PSBB), which forces Indonesians to carry out all activities at home including work, school and worship from home (WHO, 2020a). This policy is very impactful for workers whose workers cannot be done from home such as fast food restaurant chefs, cashiers, street sweepers, street vendors and many others. In fact, not a few workers have lost their jobs due to the Covid-19 pandemic. According to the CNN Indonesia news site, the Ministry of Manpower (Kemnaker) noted that the number of workers who were dismissed and laid off due to the corona virus had reached 3.06 million people. This figure is data as of May 27, 2020 (Fadillah, 2015).

The negative impact of the Covid-19 pandemic does not only affect workers, but business owners are also affected. As said by the Deputy Chairperson of the Indonesian Tourism Industry Association (GIPI) Sudradjat the covid-19 pandemic has changed the habits of people who use more free time to not go to crowded places such as restaurants (WHO, 2020d). Apart from being economical, food needs are also maximized by making your own or buying at the seller closest to the house (WHO, 2020c). "The purchasing power factor has greatly decreased and has widened throughout Indonesian society due to reduced income, so that food shopping at restaurants has also decreased," said Sudradjat to Medcom.id, Monday, June 22, 2020. According to Sudradjat, the potential benefits that are huge loss for restaurant businesses due to Large-Scale Social Restrictions (PSBB) to suppress the spread of the Covid-19 pandemic (Gondouin, 2020).

In the midst of the chaos caused by the Covid-19 pandemic, all parties must work together to survive in this difficult situation, one way is to prioritize empathy for others in all fields including advertising as practiced by Burgerking Indonesia On November 3, 2020 Burgerking Indonesia conducted Empathy-based marketing communication through the official @ burgerking.id Instagram account, it is stated that Burger King urges its audience to help all restaurants that have employees from well-known restaurants to MSME restaurants and even competing restaurants by continuing to buy food there because of the crisis. As a result of the Covid19 pandemic, many restaurants have been affected and have lost quite a lot, which is more surprising that Burgerking Indonesia gives the title "ORDER FROM MCDONALD'S" and says it is okay to buy a Big Mac which is actually BurgerKing's biggest competitor. Based on the explanation above, there is empathy-based marketing communication carried out by BurgerKing Indonesia in an effort to survive in a pandemic situation (WHO, 2020b). In this regard, this study aims to determine the response of burgerking audiences, both user and non-user in response to empathy-based marketing communications conducted by Burger King Indonesia (Fadillah \& Zhenglin, 2020).

\section{Theorotocal Framework}

\section{a. Crisis Communication}

Crisis communication is a process of dialogue between the company and the public which is carried out with the aim of dealing with the crisis that is currently hitting the company (Utz, Schultz, \& Glocka, 2013). The communication strategies and tactics that organizations use when faced with this crisis can improve their post-crisis image and reputation. Crisis communication is related to the use of all available public relations tools, in order to maintain and strengthen the reputation of the organization in the long term and at times when the organization is in danger. Every day, organizations are always faced with problems (Roshan, Warren, \& Carr, 2016). Late delivery of goods, dissatisfied consumers, unfulfilled job opportunities, rising prices, and chaotic service are some of the challenges that the business world often faces. However, these problems do not always mean causing a crisis to the company (Duncan \& Moriarty, 1998).

The purpose of crisis communication is to protect and defend organizations that face public challenges to their reputation. the words protect and defend are very powerful words. and the organization's crisis communication must help it achieve the continuity of critical business processes and information flows under a crisis, disaster, or other circumstances (Moreno Esparza, 2015). 
Traditionally, crisis communication was about protecting and defending not about the greater good or the truth. At least this is how crisis communication has been felt outside the organization. but this is slowly changing. social media has played a role in this shift to become more open and transparent Hurk (Massey, 2001).

\section{b. Marketing Communication}

Marketing communication is a means by which companies try to inform, persuade and remind consumers directly or indirectly about the products and brands being sold. Marketing communications represent the "voice" of the company and its brands and are the means by which companies can create dialogue and build relationships with consumers. Marketing communication for consumers can tell or show consumers how and why a product is used, by what kind of people, and where and when (Grönroos, 2004).

Communication plays an important role in marketing because without communication, the company or brand cannot convey a message to its audience properly about the products it offers. There are at least three purposes of communication, namely marketing communications to disseminate information (informative communication); second, influence someone or anyone to make a purchase or attract consumers (persuasive communication); and third, reminding the public to make repeat purchases (communication reminders) (Eagle, Dahl, Czarnecka, \& Lloyd, 2014). Therefore, the effectiveness of marketing communications is the key to marketers' success in selling the products they have. Because in reality not all consumers know how to meet their needs, or are not aware of a product that is able to meet their needs. Consumers will look for this information. It is at this level that marketing communications plays a role by sending and disseminating information about the products on offer. Marketing communication also suggests that as a differentiator between products from a brand and similar products from other brands with marketing communications, a brand can inform its audience that the product offered is different from other brands in terms of benefits, advantages, variants provided or other differences (Finne \& Grönroos, 2017).

\section{c. Marketing Media}

Selection of the right media for marketing communication in order to make customers know, understand, determine attitudes, and make purchases is an important step in marketing communication activities. In advertising, communicators (producers) can choose one or both media to convey the message they want to convey. These media are top-the-line and below-theline media (Tiago \& Veríssimo, 2014). Above-the-line media is advertising that uses primary media such as electronic media and print media. The use of top line media has the advantage of reaching a large audience, but this also increases the costs a company must pay to advertise (Wang, Yu, \& Wei, 2012). While other media are below-the-line media, these media are minor media used to advertise products. Even though it is considered to be a minor media, advertising in the lower line media also has an important role in an advertising campaign. This is because the bottom line media can in certain ways be more effective, depending on the form of advertisement and the campaign the advertiser is trying to carry out. Jefkins (Nadda, Dadwal, \& Firdous, 2015).

However, with the development of communication media, there is now a new medium that crosses two media or a combination of ATL (above-the-line) and BTL (below-the-line), namely TTL (through-the-line). TTL includes improvements to mass and non-mass media, so that it passes through the media. TTL can be classified as new media (Peters \& Nielsen, 2013). An example is a social network, where social media offers a wide reach with a fast and simultaneous time but also at a low cost and is personal, there are features to interact with each other between marketers and audiences.

\section{d. Empathy}

Empathy is our ability to put ourselves in situations or conditions faced by others. One of the prerequisites for having an empathetic attitude is our ability to listen or understand first before being heard or understood by others (Floreddu \& Cabiddu, 2016).

In particular, Covey embraces the ability to listen as one of the 7 very effective human habits, namely the habit of understanding first, then understanding (seek first to understand. Understand than be understood to bulid the skills of emphatic listening that inspires openness and trust). This is

W: http://journal2.uad.ac.id/index.php/commicast/index |E: commifast@comm.uad.ac.id 
what he calls empathic communication. By understanding and listening to others first, we can build the openness and trust we need to build collaboration or synergy with others (Robinson, 2018).

Empathy allows us to convey messages in ways and attitudes that will make it easier for the receiver to receive them. Therefore, in the science of marketing understanding consumer behavior is a must. By understanding consumer behavior, we can empathize with the needs, wants, interests, hopes and pleasures of consumers (Danaher \& Rossiter, 2011).

\section{c. Burger King}

Burger King Corporation is a chain of international fast food restaurants that sell burgers, fries and soft drinks. Burger King's first restaurant was named Insta Burger King and opened in 1954 in Miami, Florida, United States. Burger King first arrived in Indonesia in the 1980s and was closed in 1998 after being hit by the monetary crisis. In April 2007, Burger King returned to Indonesia and started to be operated by Mitra Adiperkasa (which also operates the Starbucks and Domino's Pizza franchises), with its first outlet in Senayan City, Jakarta. Currently, Burger King has branches in various cities in Indonesia (Mockford, 2009).

\section{Method}

This research approach uses a qualitative approach. While the method used in this research is interview. An interview is a planned direct meeting between the interviewer and the interviewee to provide or receive certain information (Sarifudin et al., 2020).

The subjects to be examined are users and non-users of BurgerKing, namely women, men, 1825 years, SES B, C and live in urban areas. This subject was chosen because this classification is the main target audience of Burgerking.

\section{Results and Discussion}

\section{a. Empathy Based Marketing Communication by Burger King Indonesia}

On November 3, 2020 Burger King conducted empathy-based marketing communications through the official Instagram account @ burgerking.id. In the post, it was stated that Burger King appealed to its consumers to help all restaurants that have employees, from well-known restaurants to MSME restaurants and even competing restaurants, by still buying food at these restaurants. This is because indeed, with the crisis due to the Covid19 pandemic, many restaurants have been affected, causing considerable losses.

The headline of the post on Instagram is quite surprising, namely "MESSAGE FROM MCDONALD's" It's something extraordinary to mention the name of a competitor on the official account of a brand. The post says it doesn't matter if you want to buy a Big Mac, which is Burger King's biggest competitor (Ding \& Tseng, 2015). This shows that Burger King is concerned and cares about all existing restaurants. But behind these messages of concern there is a message of empathy-based marketing communication because by spreading the message of concern instantly, many of the audience actually respect Burger King and post the burgerking post. This can be seen from the number of likes which has reached 343,781 likes, much bigger than the previous Burger King post which only received 14,270 likes. It can be seen that empathy-based marketing communications especially during pandemics and crises like this really attracts attention and respect from consumers and target audiences (Knowles, 2000). 


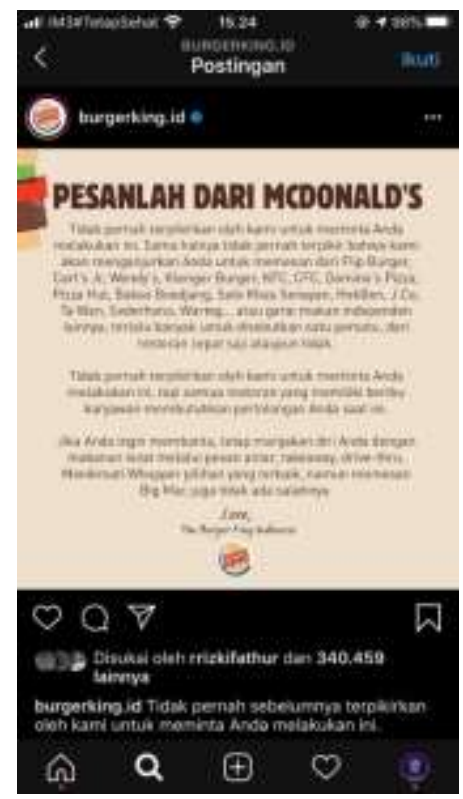

Fig. 1. Displays Burger King Instagram screenshots

\section{b. Interview result}

In conducting interviews with 8 informants, 4 users and 4 non-users of BurgerKing, the following insights were obtained: Eight sources, both user and non-user, all stated that they knew the Burger King restaurant. Four of the eight informants stated that they knew Burger King's Instagram account but did not follow the account, while the other three claimed to know that Burger King has Instagram but did not know the exact name of the Instagram account. They know Burger King owns Instagram with the assumption that a company as big as Burger King must have social media. Meanwhile, one resource person said that he had been following for a long time to get information related to promos at Burger King (Rodrigues, Nikhil, \& Jacob, 2016).

A total of seven sources stated that they were touched by the empathy-based marketing communication carried out by Burger King, but interestingly, there was one source who had difficulty digesting the advertising message. He was confused about the meaning of the ad because there was a competitor's reso name, Mc Donald on the official Instagram of Burger King.

All informants gave positive responses regarding the empathy-based marketing communication carried out by Burger King and they stated that Burger King's image was getting better in their eyes. Interestingly, five sources stated that they wanted to post the post, even as many as three sources stated that they were interested in making a purchase (R. J. Adams, 2008).

\section{c. The Use of Empathy-Based Marketing Communication in the Pandemic Era}

The Covid-19 pandemic has impacted many sectors, one of which is the economic sector, the impact of which is also felt by fast food restaurant companies. With the pandemic, fast food restaurants have to rack their brains to continue to carry out marketing communications in order to continue to spread information, influence people or anyone to make purchases and attract consumers and maintain consumer loyalty (Pfefferbaum \& North, 2020).

Brands can carry out marketing communications as usual, but it must be interspersed with empathy-based marketing because indeed in the face of a pandemic which is a common problem, we must face it together as well, namely by promoting empathy that can touch and eventually move people (Swart \& Donno, 1981). From the results of our interviews, it has been proven that empathybased marketing communication can also increase awareness and create a better brand image in the eyes of the audience, in the case of burgerking the audience is even willing to post and spread burgerking marketing communication posts voluntarily because they have been touched and finally moved (Ahmad Lutfi, Phoong Kok Hau, Anbuchelvi Shinaya, \& Khalil, 2019). 


\section{d. Media In Conducting Empathy Based Marketing Communication}

Currently, communication technology has developed greatly with the discovery of the internet and social media which is commonly called new media, so the communication media is increasingly diverse. Social media and the internet are not only communication media, but marketers also take advantage of these media for marketing (Roberto, Hoffnagle, Bragg, \& Brownell, 2010). Even in the world of marketing communications, there is a new medium for marketing communication, namely TTL which is a combination of BTL (below-the-line) and also ATL (above-the-line). TTL itself offers advertising media that can reach many audiences in a fast time like ATL (above-the-line) but at low cost and is also personal because it allows interaction between marketing and also the audience, which is something that is offered by BTL (below-the-line), one example of TTL is social media (P. C. Adams, 2016).

In the face of the Covid-19 pandemic, marketers must change their marketing strategy at the minimum cost but can reach a wide audience so that researchers recommend that the media used is better to use TTL media which is a new media in advertising, one of which is social media. Because with social media it is easier for people to access it and its spread can be quickly at a relatively cheaper cost than other media, besides that it also reduces the risk of covid because this new media can be accessed with personal gadgets which are very personal communication tools. by personal (“COVID-19 DAN IMPLIKASI BAGI USAHA MIKRO, KECIL, DAN MENENGAH,” 2020).

\section{Conclusion}

The Covid-19 pandemic has forced marketers to change their marketing communication strategies. One of the marketing communication strategies that can be carried out in the pandemic era is empathy-based marketing communication because in a crisis situation companies must continue to carry out marketing communications at least in order to survive in the pandemic era. One company that has conducted empathy-based marketing communication is Burgerking Indonesia by inviting its audience to help all restaurants ranging from fast food restaurants to umkm restaurants by continuing to buy at their infringing restaurants.

Burgerking's way of doing empathy-based marketing communications during the pandemic was considered quite brilliant and received a positive response from the audience, this can be seen from the number of likes on this post which has reached 343,781 likes which, if we compare it to the previous burgerking post, only received 14,270 likes. Even the researchers also found facts in the field that the burgerking audience, both user and non-user, responded positively to the empathybased marketing communication efforts carried out by burgerking, the majority of the informants admitted that they were touched by the message conveyed by burgerking not only that they also admitted that the image of burgerking was getting better, Furthermore, there are sources who even have the desire to make a purchase and spread the message of empathy-based marketing communication carried out by burgerking (Nasution, Erlina, \& Muda, 2020).

From this explanation, it can be concluded that the strategy of using empathy-based marketing communication in the pandemic era by utilizing social media is very appropriate and effective. Because indeed, during a pandemic, many parties need assistance, so efforts to help each other are a positive step to survive in the pandemic era. With marketing communications in the pandemic era, the company's image will improve and be increasingly viewed positively by the audience. This can have long-term consequences because a positive image can attract consumers and make consumers loyal even after the pandemic.

\section{Acknowledgment}

The author would like to thank the Communication Science Study Program of the Faculty of Social and Political Sciences, Muhammadiyah University of Jakarta and those who have helped the research process, especially the speakers who have been willing to be interviewed. The author would also like to thank Burger King Indonesia for inspiring the author to conduct this research. 


\section{References}

Adams, P. C. (2016). Media. In The Ashgate Research Companion to Critical Geopolitics. https://doi.org/10.4324/9781315612874-24

Adams, R. J. (2008). Fast food and animal rights: An examination and assessment of the industry's response to social pressure. Business and Society Review. https://doi.org/10.1111/j.1467-8594.2008.00322.x

Ahmad Lutfi, R., Phoong Kok Hau, Anbuchelvi Shinaya, \& Khalil, Z. M. (2019). Marketing Strategy of small medium enterprise (SME) in Malaysia: Consumer Market, Market Segments and Brand Positioning of Ramly Group, A Food Processing Company. International Journal of Business and Management Invention (IJBMI).

COVID-19 DAN IMPLIKASI BAGI USAHA MIKRO, KECIL, DAN MENENGAH. (2020). Jurnal Ilmiah Hubungan Internasional. https://doi.org/10.26593/jihi.v0i0.3870.59-64

Danaher, P. J., \& Rossiter, J. R. (2011). Comparing perceptions of marketing communication channels. European Journal of Marketing. https://doi.org/10.1108/03090561111095586

Ding, C. G., \& Tseng, T. H. (2015). On the relationships among brand experience, hedonic emotions, and brand equity. European Journal of Marketing. https://doi.org/10.1108/EJM-04-2013-0200

Duncan, T., \& Moriarty, S. E. (1998). A communication-based marketing model for managing relationships. Journal of Marketing. https://doi.org/10.2307/1252157

Eagle, L., Dahl, S., Czarnecka, B., \& Lloyd, J. (2014). Marketing Communications. In Marketing Communications. https://doi.org/10.1017/9781315848860

Fadillah, D. (2015). MODEL KOMUNIKASI "WOM" SEBAGAI STRATEGI PEMASARAN EFEKTIF. HUMANIKA, 15(1). https://doi.org/10.21831/hum.v15i1.7642

Fadillah, D., \& Zhenglin, L. (2020). Media power in Indonesia; oligarch, citizens and the digital revolutions. Asian Journal of Communication. https://doi.org/10.1080/01292986.2020.1808690

Finne, ̊., \& Grönroos, C. (2017). Communication-in-use: customer-integrated marketing communication. European Journal of Marketing. https://doi.org/10.1108/EJM-08-2015-0553

Floreddu, P. B., \& Cabiddu, F. (2016). Social media communication strategies. Journal of Services Marketing. https://doi.org/10.1108/JSM-01-2015-0036

Gondouin, B. (2020). COVID-19. Nephrologie et Therapeutique. https://doi.org/10.1016/S17697255(20)30419-3

Grönroos, C. (2004). The relationship marketing process: Communication, interaction, dialogue, value. Journal of Business and Industrial Marketing. https://doi.org/10.1108/08858620410523981

Knowles, C. (2000). Burger King, Dunkin Donuts and community mental health care. Health and Place. https://doi.org/10.1016/S1353-8292(00)00024-1

Lestari, P., \& Sularso, S. (2020). The COVID-19 impact crisis communication model using gending jawa local wisdom. International Journal of Communication and Society, 2(1), 47-57. https://doi.org/10.31763/ijcs.v2i1.150

Massey, J. E. (2001). Managing organizational legitimacy: Communication strategies for organizations in crisis. Journal of Business Communication. https://doi.org/10.1177/002194360103800202

Mockford, S. (2009). BURGER KING. Rugby World.

Moreno Esparza, G. A. (2015). Communication Power. Comunicación y Sociedad. https://doi.org/10.32870/cys.v0i15.1148

Nadda, V. K., Dadwal, S. S., \& Firdous, A. (2015). Social media marketing. In Handbook of Research on Integrating Social Media into Strategic Marketing. https://doi.org/10.4018/978-1-4666-8353-2.ch021

Nasution, D. A. D., Erlina, E., \& Muda, I. (2020). Dampak Pandemi COVID-19 terhadap Perekonomian Indonesia. Jurnal Benefita. https://doi.org/10.22216/jbe.v5i2.5313

W: http://journal2.uad.ac.id/index.php/commicast/index |E: commifast@comm.uad.ac.id 
Peters, B., \& Nielsen, R. K. (2013). New media. In The Handbook of Communication History. https://doi.org/10.4324/9780203149119

Pfefferbaum, B., \& North, C. S. (2020). Mental Health and the Covid-19 Pandemic. New England Journal of Medicine, 383(6), 510-512. https://doi.org/10.1056/NEJMp2008017

Roberto, C. A., Hoffnagle, E., Bragg, M. A., \& Brownell, K. D. (2010). An observational study of consumer use of fast-food restaurant drive-through lanes: Implications for menu labelling policy. Public Health Nutrition. https://doi.org/10.1017/S136898001000039X

Robinson, N. (2018). Empathy. In Visual Global Politics. https://doi.org/10.4324/9781315856506

Rodrigues, J., Nikhil, S., \& Jacob, S. (2016). Promotional Strategies of McDonalds and Market Effects. Journal of Management Research and Analysis. https://doi.org/10.5958/2394-2770.2016.00007.7

Roshan, M., Warren, M., \& Carr, R. (2016). Understanding the use of social media by organisations for crisis communication. Computers in Human Behavior. https://doi.org/10.1016/j.chb.2016.05.016

Sarifudin, Evendi, H. H., Jumasa, M. A., Surjono, H. D., Hasana, S. N., Maharany, E. R., ... Samatowa, U. (2020). Metode Penelitian Kuantitatif, Kualitatif, dan R \& D. In JPM : Jurnal Pendidikan Matematika.

Sohrabi, C., Alsafi, Z., O’Neill, N., Khan, M., Kerwan, A., Al-Jabir, A., ... Agha, R. (2020). World Health Organization declares global emergency: A review of the 2019 novel coronavirus (COVID-19). International Journal of Surgery. https://doi.org/10.1016/j.ijsu.2020.02.034

Swart, W., \& Donno, L. (1981). Simulation Modeling Improves Operations, Planning, and Productivity of Fast Food Restaurants. Interfaces. https://doi.org/10.1287/inte.11.6.35

Tiago, M. T. P. M. B., \& Veríssimo, J. M. C. (2014). Digital marketing and social media: Why bother? Business Horizons. https://doi.org/10.1016/j.bushor.2014.07.002

Utz, S., Schultz, F., \& Glocka, S. (2013). Crisis communication online: How medium, crisis type and emotions affected public reactions in the Fukushima Daiichi nuclear disaster. Public Relations Review. https://doi.org/10.1016/j.pubrev.2012.09.010

Wang, X., Yu, C., \& Wei, Y. (2012). Social Media Peer Communication and Impacts on Purchase Intentions: A Consumer Socialization Framework. Journal of Interactive Marketing. https://doi.org/10.1016/j.intmar.2011.11.004

WHO. (2020a). Q\&A on coronaviruses (COVID-19).

WHO. (2020b). Responding to community spread of COVID-19. Interim Guidance 7 March.

WHO. (2020c). Water, sanitation, hygiene and waste management for the COVID-19 virus. World Health Organisation.

WHO. (2020d). WHO Coronavirus disease (COVID-19) outbreak situation.

WHO Coronavirus Disease (COVID-19) Dashboard. (2020). Bangladesh Physiotherapy Journal. https://doi.org/10.46945/bpj.10.1.03.01 